\title{
Effects of high rates of nitrogen fertiliser on dairy pastures and production
}

\author{
S.L. HARRIS, J.W. PENNO and A.M. BRYANT \\ Dairying Research Corporation, Private Bag 3123, Hamilton
}

\begin{abstract}
High rates of nitrogen $(\mathrm{N})$ fertiliser $(217$ and 324 $\mathrm{kg} \mathrm{N} / \mathrm{ha} / \mathrm{y}$ ) applied during a farmlet study at No. 2 Dairy, DRC, Hamilton increased annual net herbage accumulation by $23 \%$ and $27 \%$ respectively. Increases in feed conservation and milk production reflected the extra pasture growth. On low stocked ( 3.2 cows/ha) farmlets where 219 and $330 \mathrm{kgN} / \mathrm{ha} / \mathrm{yr}$ were used, clover contents declined to $12.5 \%$ and $3.4 \%$ respectively compared with $22.8 \%$ where no $\mathrm{N}$ was used. Decreased clover content was probably a result of competition from increased growth of ryegrass. At the high stocking rate (4.5 cows/ha), $\mathrm{N}$ application resulted in clover contents of $19.6 \%$ and $7.9 \%$ respectively, compared with $23.8 \%$ where no nitrogen was used. Pasture utilisation was better on these farmlets than under the lower stocking rate, suggesting the improved utilisation of additional feed, particularly during spring, was responsible for the higher clover content. Nitrogen fixation activity was lower in pastures which received $\mathrm{N}$ fertiliser due to both the decreased clover content and a reduction in activity per clover plant. Use of $\mathrm{N}$ fertiliser potentially allowed large quantities_of silage-to-becut during spring. However, failure to accurately identify extent and timing of pasture surpluses meant the quantity and quality of silage made was poor and much of the extra pasture grown in response to nitrogen fertiliser was not utilised, particularly at the lower stocking rate. It is suggested that superimposing high rates of $\mathrm{N}$ fertiliser on to existing dairying systems will not significantly improve animal performance and may have a negative effect on clover content and pasture quality. To fully realise the benefits of extra $\mathrm{N}$ fertiliser use, stocking rates and/or conservation policies have to be modified.
\end{abstract}

Keywords: conservation, dairying, milk production, nitrogen fertiliser, pasture production, Trifolium repens

\section{Introduction}

Tactical application of nitrogen $(\mathrm{N})$ fertiliser to dairy pastures is an effective way of overcoming short-term feed deficits often experienced by the dairy herd (O'Connor et al. 1990). Tactical $\mathrm{N}$ use has increased markedly in recent years because of the decreased cost of $\mathrm{N}$ fertiliser, relative to product prices (Roberts et al. 1992). However, use of large quantities of $\mathrm{N}$ fertiliser to increase annual pasture production, beyond that required to overcome short-term feed deficits, has often been discouraged as uneconomic and impractical (Holmes 1982; Feyter et al. 1985). In a farmlet trial Holmes (1982) applied $350-400 \mathrm{~kg} \mathrm{~N} / \mathrm{ha}$ resulting in extrapasture production of 2800 to $3600 \mathrm{~kg}$ dry matter (DM)/ha. At a stocking rate of over 4 cows $/ \mathrm{ha}, 400 \mathrm{~kg} \mathrm{~N} / \mathrm{ha}$ increased milk fat production by $107 \mathrm{~kg} / \mathrm{ha}$, and reduced the quantity of bought-in feed required by $1000 \mathrm{~kg} \mathrm{DM} / \mathrm{ha}$. Although uneconomic at the time, under current prices this practice could improve profitability by more than $\$ 400 / \mathrm{ha}$. A growing number of dairy farmers are realising the potential for increasing pasture and milk production by using N throughout the year (Gazzard \& Bint 1992; Barr 1993); perhaps a belated recognition of earlier evidence that dairy pastures reliant solely on symbiotic fixation by clover are N deficient (Field \& Ball 1978).

There is little information on the impact of high rates of $\mathrm{N}$ on the $\mathrm{NZ}$ dairy system or the environment. Research indicates high rates of $\mathrm{N}$ fertiliser-may-limitclover $\overline{\text { growt }}$ th by increasing competition from ryegrass and may also inhibit $\mathrm{N}$ fixation activity (Moustafa $\boldsymbol{e t}$ al. 1969; Crush et al. 1982; Murphy \& Ball 1985; Frame \& Newbould 1986; Eltilib \& Ledgard 1988; Davies 1992). For example, increased use of $\mathrm{N}$ fertiliser between 1970 and 1986 halved the clover content in UK pastures. Even with a decrease in $\mathrm{N}$ application over recent years (now less than $150 \mathrm{kgN} / \mathrm{ha} / \mathrm{y}$ ), only one fifth of agricultural swards in the UK have more than 10\% clover ground cover (Davies 1992).

High rates of $\mathrm{N}$ fertiliser_(up to $400 \mathrm{~kg} \mathrm{~N} / \mathrm{ha} / \mathrm{yr}$ ) are being used in a farmlet study to reach a target production of $1750 \mathrm{~kg}$ milksolids (fat plus protein)/ha. This paper will be report on pasture production, changes in sward characteristics, and animal performance during the first year of the trial (June 1993 -June 1994), and summarise farm management implications of $u^{\circ} \mathrm{g}$ high rates of $\mathrm{N}$ fertiliser.

\section{Trial design}

Site: Seven 6.48 ha farmlets were established at No. 2 Dairy, Dairying Research Corporation, Hamilton. The 
farmlets were balanced for soil type (Horotiu silt loam, Hamilton clay loam and Te Rapa silty peat loam) and previous treatment. Annual rainfall (June 1993 to June 1994) was $985 \mathrm{~mm}$ compared with the IO-year average of $1183 \mathrm{~mm}$. Rainfall during January, February and March totalled $167 \mathrm{~mm}$ while evapotranspiration was $398 \mathrm{~mm}$, resulting in a moisture deficit of $231 \mathrm{~mm}$.

Farmlets: Farmlets (Table 1) were stocked with high genetic merit Friesian cows. Nitrogen fertiliser was applied as urea after most grazings, except during the dry summer

Farmlet 1 (control) received no $\mathrm{N}$ fertiliser or bought-in feed, representing the system used at No 2 Dairy in the past. Farmlets 2, 3, and 4 were aimed at providing information on per cow and per ha yields of milksolids when high rates of $\mathrm{N}$ fertiliser and boughtin supplement are used in an attempt to feed the same number of cows better. Farmlets 5, 6, and 7 were aimed at providing information on per cow and per ha yields of milksolids when extra cows are used to ensure effective utilisation of the extra feed. The use of boughtin supplement reflects that using grazed pasture as the sole source of feed will result in feed deficits even when high rates of $\mathrm{N}$ are used. During spring supplement was fed to maintain a post-grazing herbage mass of $1800 \mathrm{~kg} \mathrm{DM} / \mathrm{ha}$. Throughout the rest of the year supplement was fed to achieve adequate feed intake. Surplus pasture was harvested as silage and was available to be fed back to the respective farmlets.

Table 1 Experimental details of the farmlets established at No 2 Dairy.

\begin{tabular}{lcccc}
\hline Farmlet & $\begin{array}{c}\text { Stocking } \\
\text { rate } \\
\text { (cows/ha) }\end{array}$ & $\begin{array}{c}\text { Nominal } \\
\text { nitrogen } \\
\text { fertiliser } \\
\text { (kg N/ha) }\end{array}$ & $\begin{array}{c}\text { Actual } \\
\text { nitrogen } \\
\text { fertiliser }\end{array}$ & $\begin{array}{c}\text { Bought-in } \\
\text { supplement }\end{array}$ \\
\hline 1 & 3.24 & 0 & 0 & No \\
2 & 3.24 & 0 & 0 & Yes \\
3 & 3.24 & 200 & 219 & Yes \\
4 & 3.24 & 400 & 330 & Yes \\
5 & 4.48 & 0 & 0 & Yes \\
6 & 4.46 & 200 & 215 & Yes \\
7 & 4.46 & 400 & 319 & Yes \\
\hline
\end{tabular}

\section{Measurements}

Pasture: Net herbage accumulation was calculated from the increase in herbage mass on ungrazed paddocks as measured weekly by calibrated eye assessment.

Pasture composition was sampled by ground-level clipping of herbage, before every grazing on farmlets 2, 3 and 4 or before grazing in June 1993 and in May
1994 on farmlets 5,6 and 7, to give 4 samples from 4 representative paddocks within each farmlet. A subsample was dissected into ryegrass, white clover, other species and dead material before drying at $100^{\circ} \mathrm{C}$ for $24 \mathrm{~h}$ and weighing.

Nitrogen fixation activity was measured before each grazing in a representative paddock on each of the low stocked farmlets only. Selection of paddocks with the same time interval from the previous grazing allowed comparison of data across the $\mathrm{N}$ treatments. Activity ( $\mathrm{kg} \mathrm{N}$ fixed/ha/day) was measured in 5 batches of pasture cores using the acetylene reduction assay (Hoglund et al. 1979). Clover plant density data collected at the same time from the same representative paddocks allowed calculation of specific $\mathrm{N}$ fixation activity (kg N fixed/plant/day). Soil cores were collected every 6 months and clover roots and nodules washed out and dry weighted $\left(100^{\circ} \mathrm{C}\right.$ for $\left.24 \mathrm{~h}\right)$ to provide a measure of the nodule DW:root DW ratio under each $\mathrm{N}$ treatment.

Animal: Weekly milk yield and composition (fat, protein and lactose) were measured for each cow. Cows were weighed and condition scored fortnightly.

\section{Results and Discussion}

\section{Nitrogen effects on pasture production}

Nitrogen application resulted in large'increases in net herbage accumulation rates (Table 2). Annual net herbage accumulation was increased by $23 \%$ on farmlets 3 and 6 (217 kg N/ha) and $27 \%$ on farmlets 4 and 7 (324 kg N/ha) compared with farmlets 2 and 5 where no $\mathrm{N}$ was used. Large pasture responses to $\mathrm{N}$ fertiliser were achieved during winter and spring (Table 3 ). Summer $\mathrm{N}$ responses were variable and no $\mathrm{N}$ response was measured over autumn.

\section{Nitrogen effects on pasture composition}

Initially all low stocked farmlets had a similar clover content but by mid November the \% clover content on the $\mathrm{N}$ fertiliser farmlets had declined (Figure 1). Clover content was lowest on all three farmlets after dry conditions in February/March, with the effect on farmlet 4 particularly severe, so that by the end of.March there was less than $1 \%$ clover in these pastures (Figure 1). Clover content on the low stocked farmlets recovered after the rain in April and May, but with a less marked recovery on farmlets 3 and 4 , due possibly to application of $90 \mathrm{~kg} \mathrm{~N} / \mathrm{ha}$ in early April (Figure 1).

The reduced clover content following $\mathrm{N}$ application was probably a result of increased competition from ryegrass. In mixed (ryegrasslwhite clover) swards, N fertiliser increases the ability of ryegrass to compete 
Table 2 Net herbage accumulation (kg DM/ha).

\begin{tabular}{lccccccc}
\hline Farmlet & 1 & 2 & 3, & 4 & 5 & 6 & 7 \\
\hline $\begin{array}{l}\text { Winter } \\
\text { (Jon-Aug) }\end{array}$ & 2067 & 1943 & 2899 & 3237 & 2065 & 2710 & 2989 \\
$\begin{array}{l}\text { Spring } \\
\text { (Sep-Nov) }\end{array}$ & 5965 & 6207 & 6986 & 8680 & 6121 & 7782 & 8476 \\
$\begin{array}{l}\text { Summer } \\
\text { (Dec-Feb) }\end{array}$ & 5660 & 5376 & 6243 & 6154 & 5863 & 6761 & 5072 \\
Autumn & 472 & 822 & 872 & 494 & 924 & 1252 & 1126 \\
(Mar-May) & & & & & & & \\
Total & 14164 & 14348 & 16900 & 18573 & 14973 & 1850516463 \\
Extra pasture & & & 2552 & 4225 & & 3532 & 3490 \\
\hline
\end{tabular}

Table3 Seasonal pasture responses to $\mathrm{N}$ fertiliser application.

\begin{tabular}{|c|c|c|c|c|}
\hline & \multicolumn{2}{|c|}{--- Farmlets 3 and 6 --- } & \multicolumn{2}{|c|}{--- Farmlets 4 and 7 --- } \\
\hline & $\begin{array}{l}N \text { applied } \\
\text { (kg Nha) }\end{array}$ & $\begin{array}{cc}N & \text { response } \\
(\mathrm{kg} & \mathrm{DM} / \mathrm{kg} \mathrm{N})\end{array}$ & $\begin{array}{l}\mathrm{N} \text { applied } \\
(\mathrm{kg} \mathrm{N} / \mathrm{ha})\end{array}$ & $\begin{array}{c}\mathrm{N} \text { response } \\
(\mathrm{kg} \text { DM/kg N})\end{array}$ \\
\hline $\begin{array}{l}\text { Winter } \\
\text { (Juṇ-Aug) }\end{array}$ & $\begin{array}{c}42 \\
\text { (May-Jui) }\end{array}$ & $\begin{array}{c}19 \\
\text { (May-JuJ) }\end{array}$ & 73 & 15 \\
\hline $\begin{array}{l}\text { Spring } \\
\text { ( S e p-Nov) }\end{array}$ & $\begin{array}{c}53 \\
\text { (Aug.Oct) }\end{array}$ & $\begin{array}{c}22 \\
\text { (Aug-Oct) }\end{array}$ & 99 & 24 \\
\hline $\begin{array}{l}\text { Summer } \\
(\mathrm{De} \text { e - F e b ) }\end{array}$ & $\begin{array}{c}36 \\
\text { (Nov-Jan) }\end{array}$ & (Nov-Jan) & 72 & 5 \\
\hline $\begin{array}{l}\text { Autumn } \\
\text { (Mar-May) }\end{array}$ & $\begin{array}{c}86 \\
\text { (Feb-Apr) }\end{array}$ & (Feb-Apr) & 80 & 0 \\
\hline Total $\mathrm{N}$ applie & ed 217 & 324 & & \\
\hline
\end{tabular}

Figure 1 Pasture composition (\% of total DM) on low stocked farmlets at No. 2 Dairy. White clover ( (

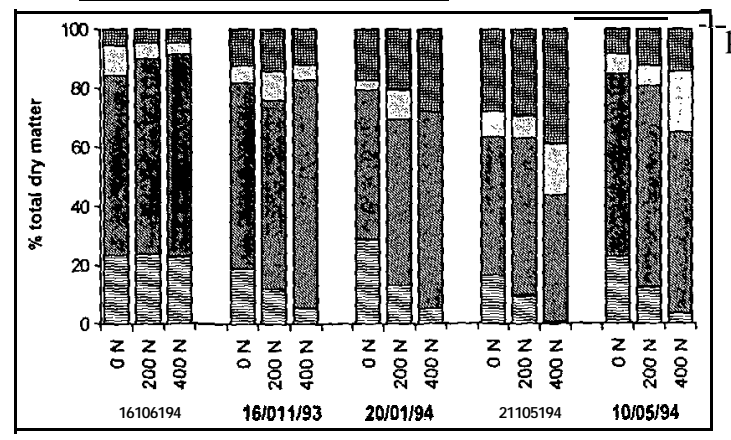

for light, water and nutrients, since the ryegrass can accumulate more of the applied $\mathrm{N}$ than clover (Murphy $\&$ Ball 1985). The ryegrass contents of pastures in the No. 2 Dairy trial were higher by late August on farmlets 3 and 4, which had received 45 and $90 \mathrm{~kg} \mathrm{~N} /$ ha respectively, than on farmlet 2 (no N). Similar trends in ryegrass contents remained throughout spring and summer (Figure 1), until March when differences disappeared as a result of a dry summer.
The clover contents ( $\%$ total DM) on farmlets 5,6 and 7 , which were stocked at 4.5 cows/ha, were measured in June 1993 and again in May 1994. The clover contents on farmlets 6 and 7 were considerably higher in May 1994 than on farmlets 3 and 4 which had received the same amount of $\mathrm{N}$ fertiliser respectively but had a lower stocking rate (Table 4). Maintenance of a higher clover content in the sward was probably due to better utilisation of spring pasture under the higher stocking rate and therefore reduced competition from ryegrass.

Table 4 White clover content (\% total DM) on low stocked (LSR) and high stocked (HSR) farmlets in May 1994. Four herbage samples (cut to ground level) were removed from each of four representative paddocks within each farmlet and dissected into white clover and other herbage [including dead material). S.E. are given in parentheses.

\begin{tabular}{ccrrr}
\hline $\begin{array}{c}\text { N applied to date } \\
(\mathrm{kg} \mathrm{N} / \mathrm{ha})\end{array}$ & $\begin{array}{c}\text { Clover content } \\
\text { LSR }\end{array}$ & $\begin{array}{c}\text { (\% of total DM) } \\
\text { H S R }\end{array}$ \\
\hline 0 & 22.6 & $(1.1)$ & 23.8 & $(4.9)$ \\
200 & 12.5 & $(3.4)$ & $19.6 \quad(3.8)$ \\
336 & 3.4 & $(2.0)$ & $7.9 \quad(1.6)$ \\
\hline
\end{tabular}

\section{Nitrogen fixation activity}

Since mid-August, $\mathrm{N}$ fixation activity was consistently higher on farmlet 2 (no $\mathrm{N}$ ) than on either farmlet 3 or 4 (Figure 2). This reflected the greater clover content of pasture and the higher $\mathrm{N}$ fixation activity ( $\mathrm{N}$ fixed/ p\&it/day)-of-clover-plants-on-farmlet 2 than on the farmlets receiving $\mathrm{N}$ fertiliser. The lower $\mathrm{N}$ fixation activity of $\mathrm{N}$-treated plants was associated with a reduction in the mass of $\mathrm{N}$-fixing nodules.

Figure2 Nitrogen fixation activity (measured using acetylene reduction assay) on low stocked farmlets at No. 2 Dairy. Bars show S.E.

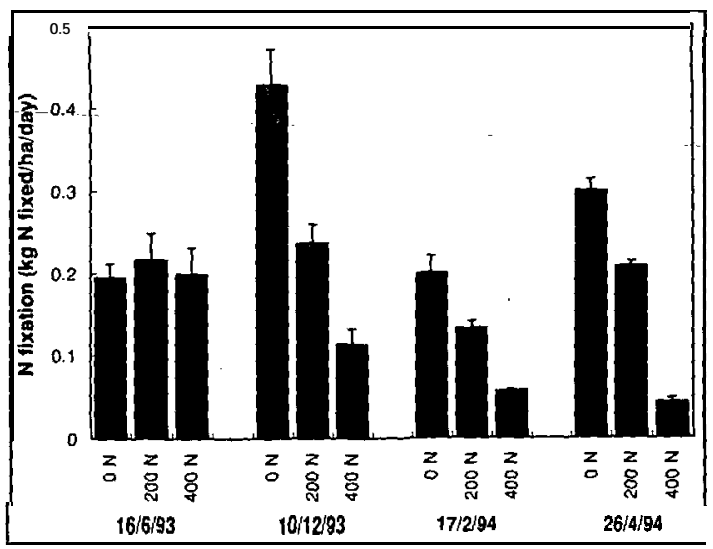




\section{Conservation}

Nitrogen accentuated the seasonality of pasture production making matching feed demand to supply more difficult. Extra pasture in the spring potentially allowed large quantities of silage to be made. On farmlet 4, for example, $3450 \mathrm{~kg}$ DM was surplus to herd requirements over spring. However, because actual pasture production exceeded predictions, only $1650 \mathrm{~kg}$ DM (48\%) of the extra pasture grown in the spring was actually made into silage. Since not all surplus pasture was removed, average cover on farmlets 3 and 4 increased through spring (Table 5). In late spring the amount of pasture on farmlets 3 and 4 was up to 665 $\mathrm{kg} \mathrm{DM} / \mathrm{ha}$ higher than farmlet 2 . Reduced grazing pressure through spring resulted in poor pasture quality with a lower clover content and an accumumlation of dead material within the sward, leading to poor milk production in late spring and early summer.

Pasture utilisation during spring on farmlets which received $\mathrm{N}$ was greater at the high than the low stocking rate. Despite more of the extra pasture being eaten at the high stocking rate, utilisation of $\mathrm{N}$-boosted pasture was still poor. For example, herd 7 required $2400 \mathrm{~kg}$ $\mathrm{DM} /$ ha less supplement than herd 5 over the season, which only accounts for $68 \%$ of the extra $3490 \mathrm{~kg}$ DM/ha pasture grown on farmlet 7. Surplus pasture

Table 5 Average pasture mass (kg DM/ha).

\begin{tabular}{lccccccc}
\hline Farmlet & 1 & 2 & 3 & 4 & 5 & 6 & 7 \\
\hline $\begin{array}{l}\text { Winter } \\
\text { (Jun-Aug) }\end{array}$ & 2276 & 2281 & 2464 & 2517 & 2404 & 2516 & 2497 \\
$\begin{array}{l}\text { Spring } \\
\text { (Sep-Nov) }\end{array}$ & 2763 & 2831 & 3307 & 3496 & 2455 & 2817 & 3069 \\
$\begin{array}{l}\text { Summer } \\
\text { (Dec-Feb) }\end{array}$ & 3522 & 3593 & 3622 & 3786 & 3426 & 3596 & 3812 \\
$\begin{array}{l}\text { Autumn } \\
\text { (Mar-May) }\end{array}$ & 3655 & 2666 & 3097 & 3151 & 2764 & 2930 & 3001 \\
\hline
\end{tabular}

was not recognised early enough, allowing pasture cover to increase, resulting in reduced pasture quality and a higher proportion of dead material in the sward over summer (Figure 1).

\section{Animal performance (Table 6)}

Of the low stocked farmlets, only herd 2 required any supplement through spring and early summer. Large quantities of supplement were required by all the high stocked herds. Herd 5 was supplemented at varying levels throughout lactation and consumed over 1250 $\mathrm{kg}$ DM/cow, 38\% of their total diet DM. Herds 6 and 7 were not supplemented through the late spring and early summer, but in total supplements still accounted for about $20 \%$ of the diet. A $3.5 \%$ increase in feed supply increased per cow performance by $18 \%$ at the low stocking rate.

\section{Conclusions and implications}

This early report of a continuing trial highlights some of the implications of using high rates of $\mathrm{N}$ fertiliser to increase pasture production. Farmers should be aware of the potential impacts, some of them long term, of high $\mathrm{N}$ use on white clover, and how a reduction in the clover content of pasture may lower feed quality. The point at which increased $\mathrm{N}$ fertiliser use and improved grass growth does not compromise feed quality or white clover content needs to be determined. Careful utilisation of the additional feed resulting from increased $\mathrm{N}$ fertiliser use, particularly in spring, may be necessary to ensure clover is not completely lost from the sward.

Results show that superimposing extra feed inputs on the existing farming system are unlikely to result in large increases in milksolids production. Although a stocking rate of 3.2 was optimum in a low input farming system at No 2 Dairy, when pasture production is increased by $20-30 \%$ through using $\mathrm{N}$ fertiliser, a

Table6 Production summary.

\begin{tabular}{lccccccc}
\hline Farmlet & 1 & 2 & 3 & 4 & 5 & 6 \\
\hline Stocking rate & 3.24 & 3.24 & 3.24 & 3.24 & 4.48 & 4.48 & 4.48 \\
Nominal N rate (kg N/ha) & 0 & 0 & 200 & 400 & 0 & 200 & 400 \\
N applied (kg N/ha) & 0 & 0 & 219 & 330 & 0 & 215 & 319 \\
Total Supplement (kg DM/cow) & 0 & 747 & 572 & $\mathbf{5 7 8}$ & $\mathbf{1 7 1 7}$ & 1213 \\
Days in milk & 247 & $\mathbf{2 8 9}$ & $\mathbf{2 8 4}$ & $\mathbf{2 8 8}$ & $\mathbf{2 8 8}$ & $\mathbf{2 8 4}$ & $\mathbf{2 8 6}$ \\
Milk kg/cow & 4255 & 5083 & 5016 & 5201 & 4530 & 4666 & 4743 \\
Milk fat kg/cow & 206 & 233 & 238 & 239 & 217 & 226 & 229 \\
Milk fat kg/ha & 666 & 755 & 770 & 773 & 971 & 1014 & 1024 \\
Milk protein kg/cow & $\mathbf{1 5 1}$ & 175 & $\mathbf{1 7 4}$ & fao & 161 & $\mathbf{1 6 8}$ & $\mathbf{1 6 8}$ \\
Milk protein kg/ha & $\mathbf{4 8 8}$ & 566 & 565 & $\mathbf{5 8 4}$ & 722 & $\mathbf{7 5 1}$ & $\mathbf{7 5 3}$ \\
Milk solids kg/cow & 356 & $\mathbf{4 0 8}$ & 412 & 419 & $\mathbf{3 7 8}$ & 394 & 397 \\
Milksolids kg/ha & 1155 & 1321 & 1335 & 1357 & 1692 & 1765 & 1778 \\
Cow condition & 4.5 & 4.5 & 4.6 & 4.5 & 5.1 & 4.8 & 4.9 \\
Silage made (kg DM/cow) & 159 & 106 & 443 & 514 & 0 & 0
\end{tabular}


stocking rate of 3.2 cows/ha was too low to fully utilise the extra feed. Nitrogen fertiliser increased pasture production through most of the year, implying a higher stocking rate is necessary to utilise the extra feed.

In order for high rates of $\mathrm{N}$ fertiliser to be profitable, management systems that efficiently utilise the extra pasture grown must be developed. Successful exploitation of the high $\mathrm{N}$ systems clearly needs accurate prediction of the magnitude and timing of the pasture surpluses. The fact they generate such large surpluses emphasises that an essential part of the required system is a preparedness and ability to make large quantities of silage. This extra effort and expense will be largely wasted unless the making, storage, and handling of that silage ensures a high quality product that results in substantial responses in extra milk when it is fed back into the system.

Changes to the farming system to ensure effective utilisation of the extra feed are as important as generating the extra feed itself.

\section{ACKNOWLEDGEMENTS}

The authors thank Kevin Macdonald for management of No. 2 Dairy and Fiona Clarkson, Deanne Waugh and Geraldine Bourke for assistance with field work.

\section{REFERENCES}

Barr, S.J. 1993. Farming with nitrogen fertiliser. Proceedings of the Massey Dairy Farmers Conference 1993: 63-67.

Crush, J.R.; Cosgrove, G.P.; Brougham, R.W. 1982. The effect of nitrogen fertiliser on clover nitrogen fixation in an intensively grazed Manawatu pasture. $N Z$ journal of experimental agriculture 10: 395 $399^{\prime}$

Davies, A. 1992. White clover. Biologist 39: 129-133.

Eltilib, A.M.; Ledgard, S.F. 1988. Production and nitrogen fixation by 'Grasslands Kopu' and 'Grasslands Huia' white clovers under different nitrogen regimes. $N Z$ journal of agricultural research 31: 325-330.

Feyter, C.; O'Connor, M. B.; Addison, B. 1985. Effects of rates and times of nitrogen application on the production and composition of dairy pastures in Waikato district, New Zealand. NZ journal of experimental agriculture 13: 247-252.

Field, T.R.O.; Ball, R. 1978. Tactical use of fertiliser nitrogen. Procedings of the Agronomy Society of New Zealand 8: 129-133.

Frame, J.; Newbould, P. 1986. Agronomy of white clover. Advances in agronomy 40: 1-88.

Gazzard, J.; Bint, M. 1992. Experience with nitrogen -is it feed or fertiliser? Proceedings of the Ruakura Farmers Conference 44: 84-86.

Hoglund, J.H.; Crush, J.R.; Brock, J.L.; Ball, P.R.; Carran, R.A. 1979. Nitrogen fixation in pasture XII. General discussion. NZ journal of experimental agriculture 7: 45-5 1 .

Holmes, C.W. 1982. The effect of fertiliser nitrogen on the production of pasture and milk in dairy farmlets: 1971-74. Proceedings of the New Zealand Grassland 43: 58-63.

Moustafa, E.; Ball, R.; Field, T.R.O. 1969. The use of acetylene reduction to study the effect of nitrogen fertiliser and defoliation on nitrogen fixation by field-grown white clover. NZ journal of agricultural research 12: 69 1-696.

Murphy, P.M.; Ball, P.R. 1985. Effect of early season nitrogen on nitrogen fixation in a ryegrass/white clover pasture. Proceedings of the XV International Grassland Congress: 460-46 1.

O'Connor, M.B.; Ledgard, S.F.; Feyter, C. 1990. Using nitrogen fertiliser effectively in intensive dairyingsystems. Proceedings of the R uakura Farmers Conference 42: 19-22.

Roberts, A.H.C.; Ledgard, SF.; O'Connor, M.B.; Thomson, N. A. 1992. Effective use of $\mathrm{N}$ fertiliser - Research and Practice. Proceedings of the Ruakura Farmers Conference 44: 77.83 